\title{
Effects of tumor metabolic microenvironment on regulatory $T$ cells
}

\author{
Yi-an Wang ${ }^{1,2}$, Xiao-Ling Li ${ }^{1,2}$, Yong-Zhen Mo², Chun-Mei Fan², Le Tang ${ }^{1,2}$, Fang Xiong ${ }^{2}$, Can Guo ${ }^{2}$, Bo Xiang ${ }^{1,2}$, \\ Ming Zhou ${ }^{1,2}$, Jian Ma ${ }^{1,2}$, Xi Huang ${ }^{2,3}$, Xu Wu ${ }^{2,4}$, Yong Li $i^{2,5}$, Gui-Yuan Li, ${ }^{1,2}$, Zhao-yang Zeng ${ }^{1,2^{*}}$ and Wei Xiong ${ }^{1,2,3^{*}}$
}

\begin{abstract}
Recent studies have shown that on one hand, tumors need to obtain a sufficient energy supply, and on the other hand they must evade the body's immune surveillance. Because of their metabolic reprogramming characteristics, tumors can modify the physicochemical properties of the microenvironment, which in turn affects the biological characteristics of the cells infiltrating them. Regulatory $T$ cells (Tregs) are a subset of T cells that regulate immune responses in the body. They exist in large quantities in the tumor microenvironment and exert immunosuppressive effects. The main effect of tumor microenvironment on Tregs is to promote their differentiation, proliferation, secretion of immunosuppressive factors, and chemotactic recruitment to play a role in immunosuppression in tumor tissues. This review focuses on cell metabolism reprogramming and the most significant features of the tumor microenvironment relative to the functional effects on Tregs, highlighting our understanding of the mechanisms of tumor immune evasion and providing new directions for tumor immunotherapy.
\end{abstract}

Keywords: Cancer metabolism microenvironment, Regulatory T cells, Hypoxia, Low pH, Signaling pathway

\section{Background}

A tumor is a type of polygenic disease in which malignant cell proliferation is caused by a variety of oncogenic factors that promote abnormal gene expression and regulation in the body [1]. It differs from the body's normal tissue cells, and is mainly characterized by the following ten characteristics: unlimited proliferation, resistance to apoptosis, evasion of growth inhibitory factors, invasion and metastasis, stimulation of angiogenesis, continuous production of proliferative signals, resistance to cellular energy metabolism, genomic instability, evasion of immune suppression, and enhancement of tumor-related inflammatory responses [2-4]. Acquisition of these characteristics is inseparable from changes in the cells themselves and the influence of the surrounding environment. The internal environment in which tumor cells grow is called the tumor microenvironment, which consists of the extracellular matrix, myofibroblasts, cytokines, fibroblasts,

\footnotetext{
*Correspondence: zengzhaoyang@csu.edu.cn; xiongwei@csu.edu.cn ${ }^{1}$ The Key Laboratory of Carcinogenesis of the Chinese Ministry of Health, Hunan Cancer Hospital and The Affiliated Cancer Hospital of Xiangya School of Medicine, Central South University, Changsha 410013, Hunan, China Full list of author information is available at the end of the article
}

neuroendocrine cells, adipocytes, immune-related cells, and vasculature [5-8].Tumor cells can affect the physicochemical properties, components, and cytokines of the tumor microenvironment, making it more conducive to their growth, metastasis, and invasion [9-13]. At the same time, changes in tumor microenvironment play an important role in all stages of tumor development, inhibiting or promoting tumor growth. The interaction between the two affects the whole process of tumor growth, and mutual adaptation maintains the dynamic balance of tumor microenvironment [14-19].

Owing to changes in their physiological characteristics, tumor cells promote a series of changes in the tumor microenvironment [20-23]. Rapidly growing tumor cells and mesenchymal cells lead to a decrease in local oxygen content and thus to a microenvironment in an oxygen-starved state, with the most severe hypoxia in the center of the tumor and a gradient decrease from external to internal oxygen content. Tumor growth to $1-2 \mathrm{~mm}$ in diameter stimulates local angiogenesis [24], and local hypoxia induces the expression of vascular endothelial growth factor (VEGF), which in turn promotes the formation of blood vessels in tumors $[24,25]$. However, owing to the abnormal 
tumor microenvironment, new blood vessels often have uneven distribution, large capillary distance, short arteriovenous circuit, incomplete endothelial cells, and ruptured basal membranes [26]. Therefore, these localized microvessels cannot improve the state of hypoxia. With changes in the tumor microenvironment, the metabolism of tumor cells is also quite different from that of normal cells. The most significant difference is the Warburg effect, in which, compared with normal cells, tumor cells obtain energy through anaerobic glycolysis even under oxygen-rich conditions [27, 28]. At the same time, hypoxia causes high expression levels of hypoxia-inducible factor (HIF) in cells. This in turn promotes the expression of glycolysis-related proteins [29], and changes in glucose metabolism lead to the massive production of lactic acid metabolites. An oncogene such as $c-m y c$ is activated by tumor cells and up-regulates the expression of lactate dehydrogenase A ( $\mathrm{LDH}-\mathrm{A})$ and promotes the conversion of pyruvate to lactic acid [30]. This leads to an increase in lactate content and low $\mathrm{pH}$ in tumor cells. To avoid the effects of intracellular lactic acid on basal metabolic activity, the efficiency of the monocarboxylate transporter (MCT) on the cell membrane is increased, removing excess lactic acid from the cell [31]. This causes the tumor microenvironment to be at a low $\mathrm{pH}$. HIF can induce high expression levels of carbonic anhydrase (CA) in tumor cells, which catalyzes the reaction of $\mathrm{CO}_{2}$ with $\mathrm{H}_{2} \mathrm{O}$ to generate carbonic acid [32]. Stimulation of various types of carcinogens and cytokines leads to disturbances in the acid-base balance in tumor cells. Tumor cells promote an efflux of intracellular hydrogen ions by up-regulating hydrogen ion-related transport proteins in the cell membrane [33]. The above changes will further exacerbate the low $\mathrm{pH}$ of the microenvironment. In addition, de novo synthesis of fatty acids in tumor cells is also enhanced [34, 35]. Glutamine metabolism is enhanced, and the metabolism of other amino acids and nucleic acids also changes [36, 37]. These metabolic changes promote tumor cell proliferation, metastasis, and invasion [38$40]$ and also cause changes to the microenvironment of the tumor, affecting other cells infiltrating the tumor tissue. Metabolic changes occur not only in tumor cells, but also in immune cells infiltrated in the tumor tissue that undergo metabolic reprogramming to accommodate functional changes.

During proliferation and metastasis, tumor cells need to obtain enough energy and reaction substrates to satisfy their own metabolism [41-44], and it is necessary to escape the surveillance and elimination of abnormal tissue cells by the immune system [45]. The immune evasion of tumor cells occurs in two ways: covering the self-antigens to hide or remove the target that can be recognized by the host immune system, also known as antigen coverage; or secretion of immunosuppressive cytokines to inhibit the immune effector cells or induction of suppressive immune cells to exert immunosuppressive effects [46]. Tregs belong to a T cell subgroup with regulatory immune functions. These cells participate in the immune escape of tumor cells mainly through the induction of immune incompetence and immunosuppression [47]. Clinical studies have found a large infiltration of Tregs in tumor tissues of patients, and their amount is closely related to the prognosis of patients $[48,49]$. Some tumors can be treated by reversing local Tregs levels in tumor tissue $[50,51]$. Animal experiments showed that tumor growth is positively correlated with Tregs local content in tumors, and removal of Tregs can effectively enhance the body's resistance to tumors $[52,53]$. Tregs have a strong ability to infiltrate and accumulate in tumor tissues. The chemokines in the tumor microenvironment can bind to the corresponding receptors on the surface of Tregs, recruit Tregs to the tumor tissues, and exert immunosuppressive effects [54]. Antigens in tumor tissues can promote the production of Tregs after dendritic cell processing and extraction [55]. Tumor cells secrete cytokines to directly induce the transformation of $\mathrm{T}$ cells into Tregs [56], or indirectly promote the production of Tregs by inducing the maturation of myeloid dendritic cells that secrete immunosuppressive factors [57].

Tregs are abundantly present in tumor tissues and mainly mediate immunosuppressive effects. An increasing number of studies has focused on the metabolic reprogramming of Tregs in tumor tissues and whether tumors and Tregs can influence each other, and on how to modulate Tregs or the biologically active substances or cells that affect these $\mathrm{T}$ cells in the tumor microenvironment to improve the patient's prognosis. Therefore, this review focuses on the metabolic reprogramming of Tregs in tumor tissues and the effects of the physicochemical properties of the tumor microenvironment on the generation, proliferation, and infiltration of Tregs and its mechanisms of action. Advances in understanding of the complex regulatory networks of tumor immune evasion provide a theoretical basis and new biological targets for clinical treatment.

\section{The physiological function of Tregs}

Tregs are a subset of T cells that express the interleukin (IL)-2 receptor CD25 and the forkhead/flanking helix nuclear transcription factor (Foxp3), and were first discovered in 1995 [58]. Tregs in the body are divided into two groups: natural Tregs (nTregs), which mature after positive and negative selection of the thymus and exert immunosuppressive effects in peripheral 
blood and lymphoid tissues; and inducible Tregs (iTregs), which originate after $\mathrm{T}$ cells receive antigen stimulation and are transformed by inhibitory cytokines [59], having differentiated into different subtypes by different cytokines and playing different biological roles [60] (Fig. 1/Table. 1).

Foxp3 is a key transcription factor of Tregs, mainly related to the development and function of these cells. Foxp3 regulates the immunosuppressive function of Tregs mainly through transcriptional co-regulatory proteins, including transcription factors, co-repressors, co-activators, histones, and chromatin remodeling factors, which combine to form protein complexes to dynamically regulate the expression of related genes [61-65].

Tregs exert immunosuppressive effects by inhibiting effector $\mathrm{T}$ cells and dendritic cells mainly through the following pathways: (a) secretion of perforin and granzyme B that act directly on effector cells promoting apoptosis [66]; (b) secretion of inhibitory cytokines such as transforming growth factor (TGF)- $\beta$, IL-10, and IL-35 that bind to immune cells and result in immunosuppressive effects [67]; (c) by interacting with target cells via its surface receptors, such as cytotoxic $\mathrm{T}$ lymphocyte-associated antigen (CTLA)-4, to inhibit immune function by binding to CD80/CD86 on the surface of effector cells [68], thereby inducing effector cells to secrete indoleamine 2,3 dioxygenase (IDO), which catalyzes the conversion of tryptophan in tissues to kynurenine. The loss of tryptophan inhibits the activation of effector cells and induces apoptosis [69] . The increased kynurenine not only inhibits the immune function of effector cells, but also regulates Treg proliferation and differentiation by acting on the aromatic hydrocarbon receptor (AhR) [70]. Specifically, invasive Tregs in pancreatic cancer can bind to CD80/ CD86 on the surface of dendritic cells via surface CTLA-4 to inhibit the function of dendritic cells in tissues, which, in turn, affects the function of cytotoxic $\mathrm{CD} 8+\mathrm{T}$ cells to suppress immune responses in

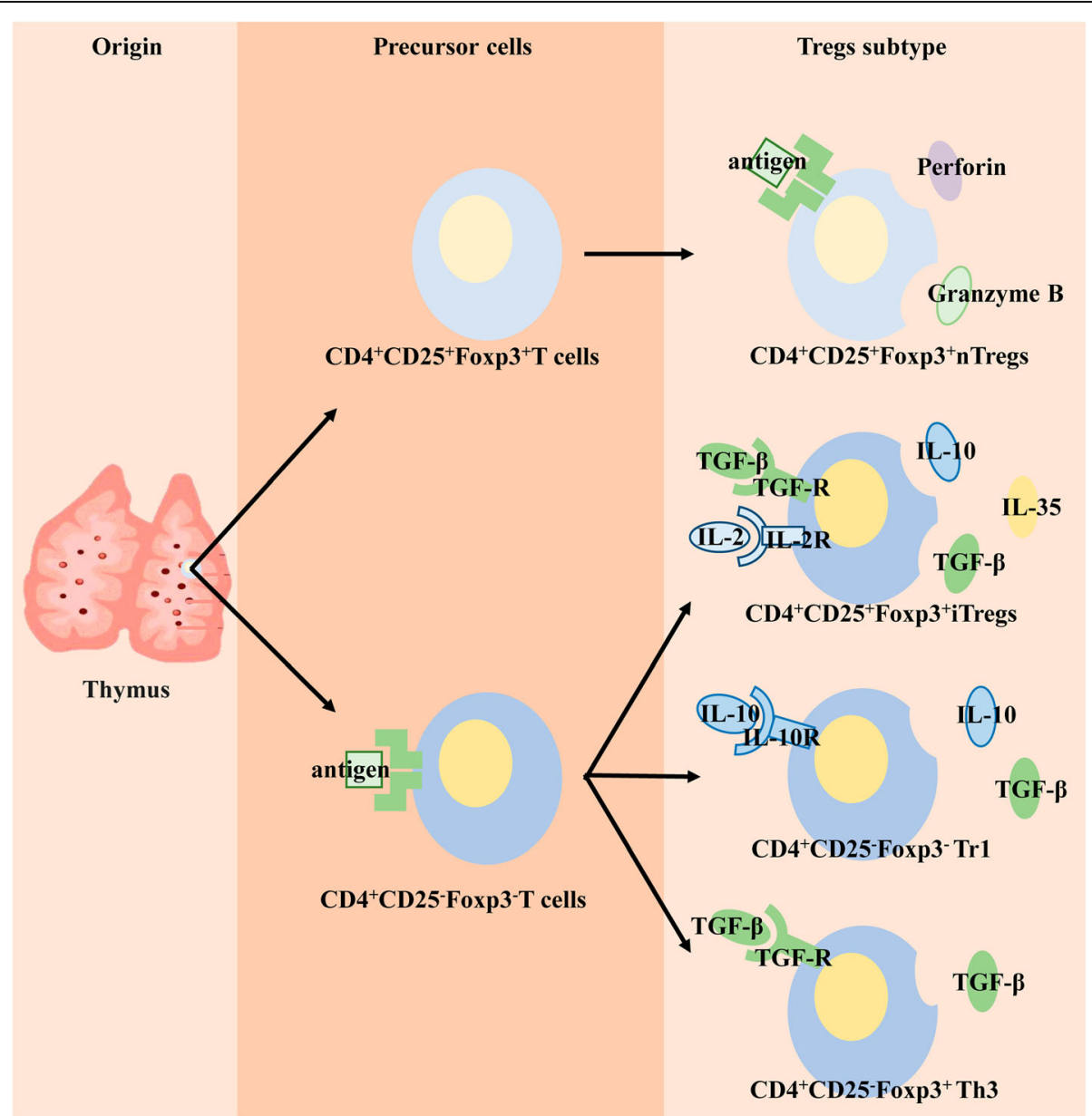

Fig. 1 Differentiation of Tregs. nTregs: mature after thymus undergoes selection and exerts an immune function in the periphery. iTregs: peripheral T cells stimulated by antigen are converted to different Tregs subtypes by different inhibitory cytokines, secreting different cytokines to play immunosuppressive roles 
Table 1 Treg subtypes and functions

\begin{tabular}{|c|c|c|c|c|}
\hline Treg classification & Treg subtype & Stimulus factor & Secretion factor & Biological role \\
\hline Natural Tregs (nTregs) & CD4 + CD25 + Foxp3 + nTregs & Antigen & Perforin, Granzyme B & $\begin{array}{l}\text { Curbs the occurrence of autoimmune diseases } \\
\text { and induces transplant tolerance }\end{array}$ \\
\hline \multirow[t]{3}{*}{ Inducible Tregs (iTregs) } & CD4 + CD25 + Foxp3 + iTregs & TGF- $\beta, I L-2$ & IL-10, IL-35, TGF- $\beta$ & $\begin{array}{l}\text { Maintains the stability of the internal environment, } \\
\text { curbs the occurrence of autoimmune diseases, } \\
\text { anti-tumor immunity, and anti-infective immunity }\end{array}$ \\
\hline & CD4 + CD25-Foxp3- Tr1 & $\mid \mathrm{L}-10$ & IL-10, TGF- $\beta$ & Inflammatory autoimmunity \\
\hline & CD4 + CD25-Foxp3+ Th3 & TGF- $\beta$ & TGF- $\beta$ & Participates in oral tolerance and mucosal immunity \\
\hline
\end{tabular}

pancreatic cancer [71]. Tregs surface also expresses costimulatory molecules belonging to the CD28 family----induced costimulatory molecules (ICOS) [72]. ICOS binds to ICOSL, a receptor on the surface of effector cells, and promotes the secretion of inhibitory cytokines, especially IL-10 [73]; and (d) conversion of intercellular ATP to adenine through the cell surface receptors CD73 and CD39, with adenine binding to the adenosine receptor A2AR on the surface of effector cells and inhibiting its proliferation and immune function [74]. (Fig. 2).

\section{Effects of metabolic reprogramming on Tregs}

As the tumor microenvironment undergoes a series of changes in physical and chemical properties, Tregs infiltrating tumor tissues are also metabolically reprogrammed to meet the needs of differentiation, proliferation, and function. Metabolic reprogramming is primarily involved in glycolysis, fatty acid oxidation (FAO), and oxidative phosphorylation (OXPHOS). Glycolysis is a process in which glucose is degraded in the cytoplasm to produce pyruvic acid and then reduced to lactic acid in an oxygen-deficient state. It can quickly provide the required energy to the cells, and the metabolites can participate in the growth and function of the cells as substrates for other reactions. FAO is a process in which intracellular fatty acids are oxidatively decomposed into $\mathrm{CO}_{2}$ and $\mathrm{H}_{2} \mathrm{O}$ by the action of related enzymes and release a large amount of energy. OXPHOS mainly occurs in mitochondria, the process by which the metabolically produced active substance is electronically coupled through the respiratory chain to ultimately couple to form ATP. These metabolic changes interact to affect the immune function of Tregs.

\section{Reprogramming of glucose metabolism affects Treg chemotaxis and immune function}

In activated Tregs, the surface molecule CD28 is stimulated to activate the downstream PI3K protein, which stimulates downstream mTORC2 activation and ultimately promotes glucokinase (GCK) expression. On the one hand, GCK can bind to actin to promote the rearrangement of the cytoskeleton and promote the migration of Tregs into tumor tissues. On the other hand, as an isozyme of hexokinase, it can promote glycolysis in Tregs and provide energy for the movement of the cytoskeleton [75].

The Toll-like receptor (TLR) on the surface of Tregs is also involved in metabolic reprogramming. After stimulation by the microenvironment, TLR1 and TLR2 activate the downstream PI3K-Akt-mTORC1 signaling pathway, resulting in the expression of glucose transporter 1 on the cell membrane. Glut1 can transport extracellular glucose into cells for glycolysis, providing the required energy for Tregs, which is beneficial to their proliferation, but the activation of this signaling pathway impairs the immunosuppressive function of these cells [76]. IL-2 and its receptors are also involved in the activation of the PI3K-Akt-mTORC1 signaling pathway [77]. The inhibitory effect on Tregs is a result of the expression of the transcription factor Foxo1/3 required for inhibition of Foxp3 expression by Akt in the signaling pathway $[78,79]$. However, FOXp3 can inhibit Tregs glycolysis by inhibiting the PI3K-AktmTORC1 signaling pathway through feedback regulation [76], and, at the same time, inhibits the expression of the transcription factor Myc [80]. As a growth factor, Myc can induce cells to undergo metabolic reprogramming such as the shift from glycolysis [81], thus indirectly inhibiting glycolysis in the cell. AMP kinase (AMPK) inhibits the expression of Glut1 and glycolysis in Tregs by inhibiting the mTORC1 signaling pathway [82]. It is speculated that glycolysis may play different roles in different functional phases of Tregs. (Fig. 3).

\section{Lipid metabolism reprogramming promotes Treg immune function}

AMPK expressed in Tregs is not only involved in the reprogramming of glucose metabolism, but also promotes FAO by increasing the expression of FAO's key enzyme, carnitine palmitoyltransferase-1A (CPT1A) [83]. PD-1 on the surface of Tregs can also promote FAO by increasing the expression of CPT1A [84]. Treg' FAO process promotes Treg proliferation, stability, and immunosuppressive function. 

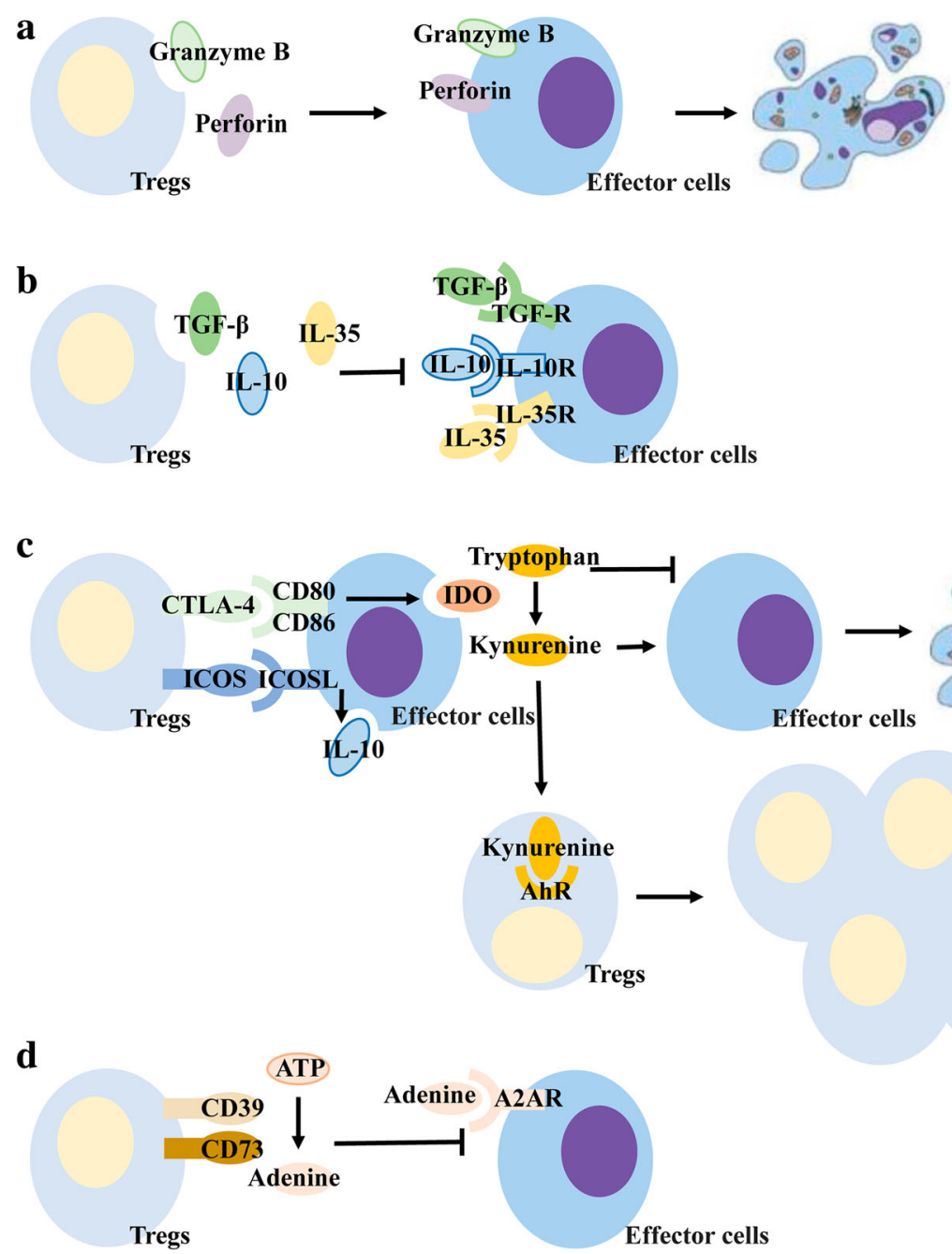

Fig. 2 Immunosuppression of Tregs. (a)Tregs secrete granzyme B and perforin that act on effector cells and cause apoptosis. (b)Tregs secrete inhibitory cytokines that bind to receptors on the surface of effector cells and inhibit the immune response. (c) CTLA-4 on the surface of Tregs competes with CD80/CD86 on the surface of effector cells to inhibit their immune function and promote the secretion of IDO; IDO degrades tryptophan in tissues to kynurenine; deletion of tryptophan leads to effector cell apoptosis; and kynurenine promotes effector cell apoptosis and acts on Tres's AhR to promote its proliferation. ICOS on the surface of Tregs binds to ICOSL on the surface of effector cells, promoting the effector cell secretion inhibitory cytokine IL-10. (d) CD73/CD39 on the surface of Tregs convert ATP in tissues to adenine, which binds to receptors on the surface of effector cells and inhibit their immune function

\section{Oxidative phosphorylation promotes Tregs immune function}

Foxp3, the most important transcription factor in Tregs, promotes mitochondrial OXPHOS by increasing the expression of mitochondria-associated genes and mitochondrial electron transport system proteins. These changes not only provide the energy needed for Tregs to exert immunosuppressive function, but also consume long-chain fatty acids in cells and protect from fatty acid-induced apoptosis [85]. Metabolic reactive oxygen species (ROS) produced during the OXPHOS process also stabilize the transcription factor-activated T cell nuclear factor (NFAT) in the nucleus [86], which binds to the non-coding sequence 2
(CNS2) of the enhancer upstream of the Foxp3 gene [87] and promotes its expression. (Fig. 4).

Treg' metabolic reprogramming mainly inhibits glycolysis and promotes FAO and OXPHOS, so that cells can adapt to changes in a tumor microenvironment with low glucose and high lactic acid and promote cell proliferation, differentiation and immune function.

\section{Effects of microenvironmental changes on Tregs}

Hypoxia in the microenvironment leads to high expression levels of the transcriptional regulatory factor, HIF, in tissue cells, which are positively correlated with the degree of hypoxia [88]. HIF is a transcriptionally 


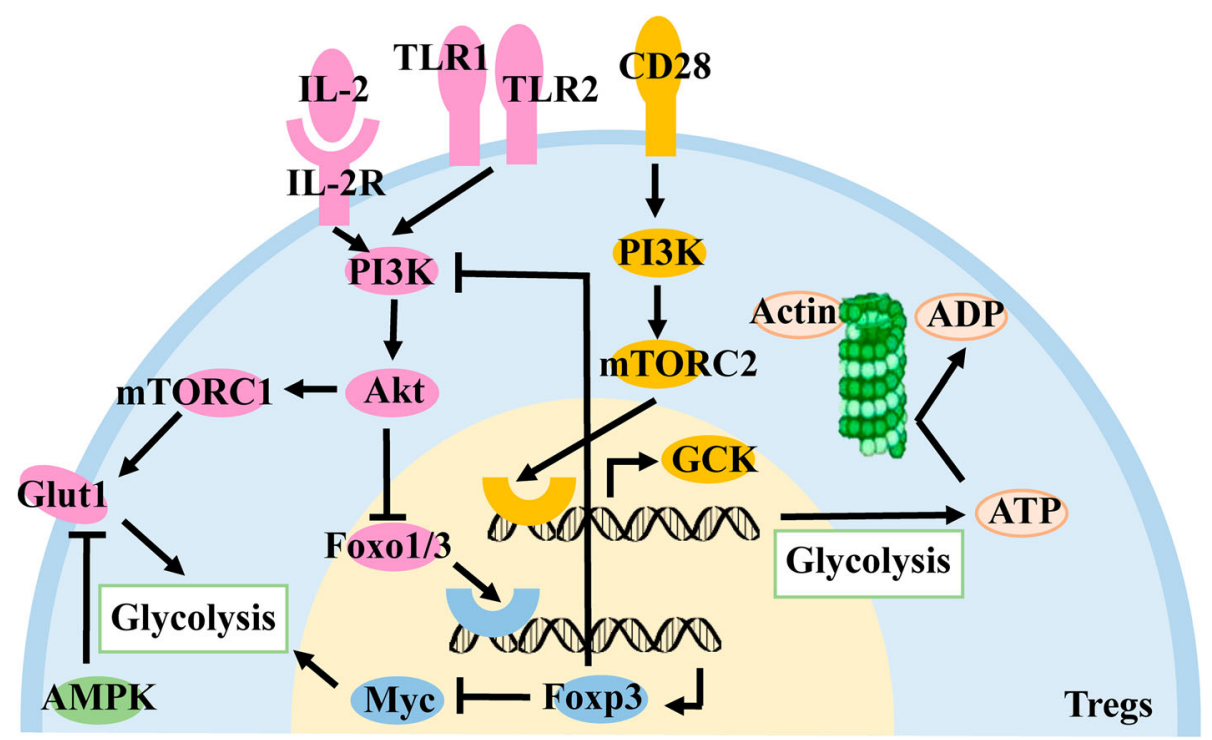

Fig. 3 Effect of glycolysis on Tregs. CD28 on the surface of Tregs is activated to promote GCK expression via PI3K/mTORC2, GCK, and actin, which can promote cytoskeletal remodeling, and GCK can promote glycolysis to provide energy. Upon stimulation of TLR1/2 or IL-2R on the Treg surface, activation of the PI3K/AKT/mTORC1 signaling pathway promotes Glut1 expression on the cell membrane surface and promotes glycolysis to promote proliferation. Akt inhibits the function of Tregs by inhibiting the expression of Foxp3, which in turn inhibits the transcription factor Fox01/3. Foxp3 inhibits glycolysis by inhibiting the signaling pathway of PI3K/AKT/mTORC1 and the expression of Myc. AMPK in Tregs inhibits glycolysis by suppressing mTORC1

active heterodimer consisting of an $\alpha$-subunit and a $\beta$ subunit. HIF- $\alpha$ has three subtypes: HIF- $1 \alpha$, HIF- $2 \alpha$, and HIF-3 $\alpha$ [89]. HIF binds to hypoxia response elements (HREs) to promote the transcription of related downstream genes and to express the encoded protein to respond to the effects of hypoxia on cells [90].

The acidic microenvironment not only promotes the release of active substances such as immunosuppressive cytokines by affecting the intracellular metabolic environment, but also affects the biological and physical properties of tumor cell membranes to promote exosome release [91]. Exosomes are small vesicles containing complex RNA and proteins for information exchange between cells [92].Caveolin-1 can also promote the release of tumor-derived exosomes under acidic conditions [91]. Similarly, microenvironment hypoxia may promote the secretion of exosomes by tumor cells by activating the HIF signaling pathway [93].

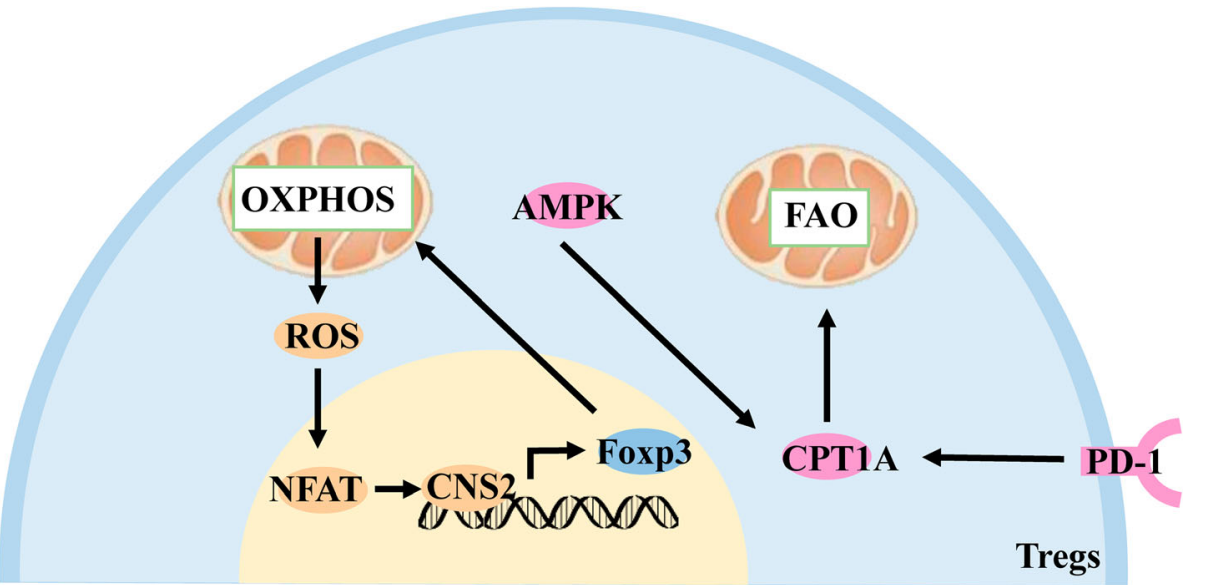

Fig. 4 Effect of FAO and OXPHOS on Tregs. AMPK in Tregs promotes FAO by increasing the expression of CPT1A. PD-1 on the surface of Tregs also promotes FAO by increasing CPT1A expression. Foxp3 promotes OXPHOS by increasing the expression of mitochondria-associated proteins, ROS, a by-product of OXPHOS, stabilizes NFAT in the nucleus and binds to CNS2 to promote Foxp3 expression 


\section{Microenvironment chemotactic signals recruit Tregs to tumor tissue}

Changes in the tumor microenvironment can affect the levels of infiltrating cell-associated chemokines in tumor cells and tissues. These chemokines, in turn, recruit Tregs to tumor tissues by chemotaxis to exert immunosuppressive effects.

Chemokines are a class of cytokines that are expressed on the cell surface or secreted into the cell mesenchyme and have a chemotactic effect on certain cell types. Chemotaxis is exerted by binding to the corresponding chemokine receptors on the cell surface. Chemokine receptors are G protein-coupled receptors that are widely expressed in various cells and are also divided into four families based on the corresponding ligands. A cross-activation between receptor and ligand is also observed.

Under hypoxia, ovarian cancer cell lines express a large number of CCL28 receptors and recruit Tregs to tumor tissues. HIF- $1 \alpha$ inhibitors reduce CCL28 levels and decrease its chemotactic ability to recruit Tregs. It is speculated that ovarian cancer cells promote the expression of CCL28 on the cell surface through the HIF signaling pathway during hypoxia, and CCL28 interacts with CCR10 on the surface of Tregs to recruit it by chemotaxis into the tumor tissue and exert immunosuppressive effects [94]. The same findings were observed in liver cancer cell lines [95].

Under hypoxic conditions, basal-like breast cancer cells exert immunosuppressive effects by affecting the expression of chemokine receptors on the surface of Tregs. HIF acts on HREs to promote the expression of CXCR4 on the surface of Tregs cells, which in turn bind to CXCL12 on the surface of tumor cells, and then Tregs are recruited by chemotaxis into tumor tissues. In addition to its direct action, HIF- $1 \alpha$ can also promote the expression of downstream Foxp3 by binding to HREs, and indirectly promote the expression of CXCR4 by acting on regulatory sequences upstream of the CXCR4 transcription initiation site [96]. This phenomenon was also observed in ovarian cancer [97], lung adenocarcinoma [98], and malignant mesothelioma [99].

Nasopharyngeal carcinoma cells secrete exosomes under the influence of the microenvironment to recruit Tregs by chemotaxis. Tumor-derived exosomes contain CCL20, which is released in the interstitial space and then binds to CCR6 on the surface of Tregs. These cells are recruited by chemotaxis to the tumor tissue and exert immunosuppressive effects [100].

The tumor microenvironment can directly recruit activated Tregs by chemotaxis into tumor tissues, or recruit $\mathrm{T}$ cells into tumor tissues that differentiate into Tregs under the stimulation of certain cytokines to exert immunosuppressive effects (Fig. 5).

\section{Microenvironment promotes differentiation of T cells into Tregs}

A large number of $\mathrm{T}$ cells are found infiltrating in the tumor tissue. These $\mathrm{T}$ cells can differentiate into immune cells of several subtypes under the influence of different cytokines in the microenvironment, thus exerting different immune effects.

HIF- $1 \alpha$ in $\mathrm{CD}^{+} \mathrm{T}$ cells is stably expressed under hypoxia and binds to HIF-1 $\beta$ in the nucleus. Subsequent binding to conserved HIF-1 binding sites on HREs promotes downstream expression of Foxp3 [101, 102]. As the main transcription factor of Tregs, Foxp 3 can regulate most gene expression related to Treg differentiation, proliferation, and immune function.

The above process is further improved [103]. The downstream regulatory genes of HIF- 1 also include TGF- $\beta$, and hypoxia can promote the expression of TGF- $\beta$ in CD4 $+\mathrm{T}$ cells. On the one hand, TGF- $\beta$ is secreted into the cell mesenchyme and binds to the corresponding receptors on the cell membrane to activate downstream signaling pathways and regulate cell differentiation. On the other hand, TGF- $\beta$ can inhibit the key enzyme PHD2 [104] in the proteasome-mediated degradation of HIF- $1 \alpha$, and thus indirectly promote the expression of HIF-1 $\alpha$ in T cells.

Hypoxia not only directly promotes the conversion of $\mathrm{T}$ cells into Tregs, but also indirectly promotes the differentiation of $\mathrm{T}$ cells into Tregs by affecting the secretion of cytokines or enhancing the expression of cell surface molecules in cells infiltrating tumor tissues. Immunohistochemistry showed co-localization of HIF$1 \alpha$ and TGF- $\beta$ in gastric cancer, suggesting that HIF-1 combined with HREs also promote the expression of downstream TGF- $\beta$ molecules in gastric cancer cells. Subsequently, TGF- $\beta$ is secreted into the cytoplasm and binds to the TGF- $\beta$ receptor on the $T$ cell membrane, promoting the downstream phosphorylation of SMAD3. The phosphorylated SMAD3 binds to SMAD4 and then the complex enters the nucleus, recruiting the coactivator $\mathrm{CBP} / \mathrm{p} 3000$ and then binding to Foxp3 regulatory sequences to promote Foxp3 expression [105].

Programmed cell death protein-1(PD-1) is an active molecule that is widely expressed on the surface of $\mathrm{T}$ cells and $B$ cells. It can bind to programmed death-ligand-1(PD-L1) and initiate downstream signaling pathways, regulating the activation of immune cells. Under hypoxic conditions, HIF-1 $\alpha$ in tumor cells, bone marrow-derived suppressor cells, and dendritic cells promotes the expression of downstream PD-L1 by acting on HREs. PD-L1 binds to PD-1 on the surface of $\mathrm{T}$ cells, causing the dephosphorylation of the downstream protein PI3K, which in turn inhibits the activation of downstream $\mathrm{AKT} / \mathrm{mTOR}$ to promote the expression of Foxp3 [106]. In renal cell carcinoma, 


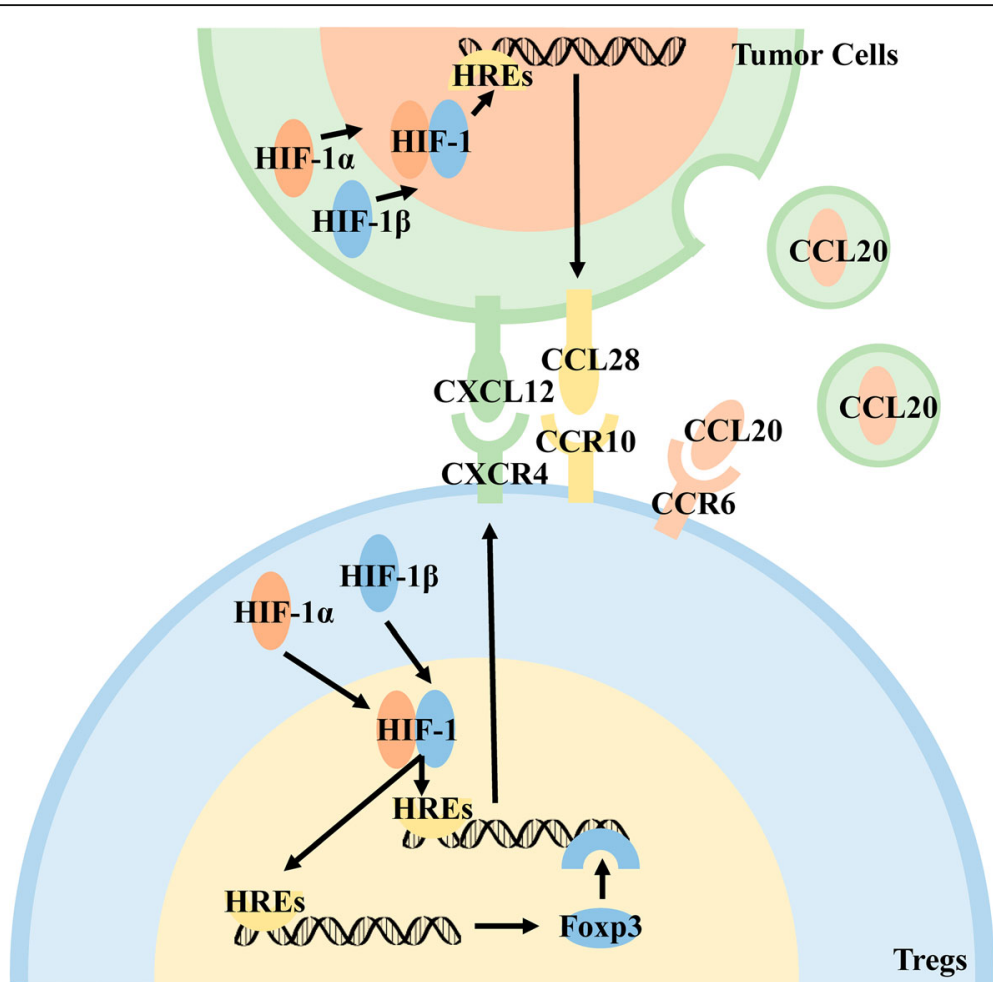

Fig. 5 The microenvironment recruits Tregs to tumor tissue by chemotaxis. Hypoxia promotes the expression of chemokines on tumor cells and Tregs surface through the HIF signaling pathway, and recruits Tregs by chemotaxis to the tumor tissue. Low pH microenvironment promotes the secretion of chemokine-containing exosomes from tumor cells that recruit Tregs to tumor tissue by chemotaxis

hypoxia mainly promotes the expression of PD-L1 by stabilizing the expression of HIF- $2 \alpha$, and then PD-1 binds to the surface of $\mathrm{T}$ cells to promote differentiation into Tregs [107] (Fig. 6).

Tumor-derived exosomes contain TGF- $\beta$ and IL-10 [108-110] and release their contents after secretion from cells. TGF- $\beta$ binds to receptors on the surface of $\mathrm{T}$ cells and differentiates into Tregs by activating the downstream SMAD signaling pathway. However, binding of IL-10 to the IL-10R on the surface of T cells activates downstream JAKs and activates the transcription factor STAT3 through phosphorylation of related molecules. Acting on STAT binding elements promotes the expression of Foxp3, which differentiates $\mathrm{T}$ cells into Tregs. Tumor-derived exogenous TGF- $\beta$ may have a greater impact on Tregs because IL-10 can only induce T-cell differentiation into Tregs, whereas TGF- $\beta$ can promote Tregs proliferation in addition to inducing differentiation.

In addition to immunosuppressive cytokines, tumor-derived exosomes also contain microRNAs (miRs) that regulate cell differentiation. Exosomes containing miR-214 can directly bind to the $\mathrm{T}$ cell membrane, transferring miR-214 into $\mathrm{T}$ cells by endocytosis, which not only promotes the secretion of IL-10 by T cells, but also binds to the 3'UTR region of PTEN, reduces the expression of
PTEN protein in cells, and activates the PI3K-Akt signaling pathway [111]. This signaling pathway enables the intracellular accumulation of the cycle-associated transcription factor E2F to promote the proliferation of Tregs [112]. PTEN is also a major regulator of Treg stability. A large number of PTEN deletions in Tregs affect PI3K-Akt regulation, leading to $\mathrm{CD} 25$ deletion, and the accumulation of Foxp $3+$ CD25-T cells ultimately leads to the loss of Foxp3 expression in these cell populations; therefore, PTEN regulates Treg lineage homeostasis and stability by inhibiting the PI3K-Akt signaling pathway [113]. Moreover PTEN can also promote the induction of the JAK-STAT signaling pathway to promote the expression of FOXp3 [114] (Fig. 7).

\section{The metabolite, RA, promotes differentiation of $\mathrm{T}$ cells into Tregs}

Metabolites in the microenvironment can also affect the function of Tregs. Retinoic acid (RA) is a metabolite of vitamin A in dendritic cells [115]. The ability of RA to directly induce the differentiation of $\mathrm{T}$ cells into Tregs is weak; however, it can significantly enhance the efficiency of TGF- $\beta$ and IL- 2 to promote the differentiation of T cells into Tregs [116]. As an important molecule that promotes the function of Tregs, IL-2 can promote the expression of Foxp3 by activating the 


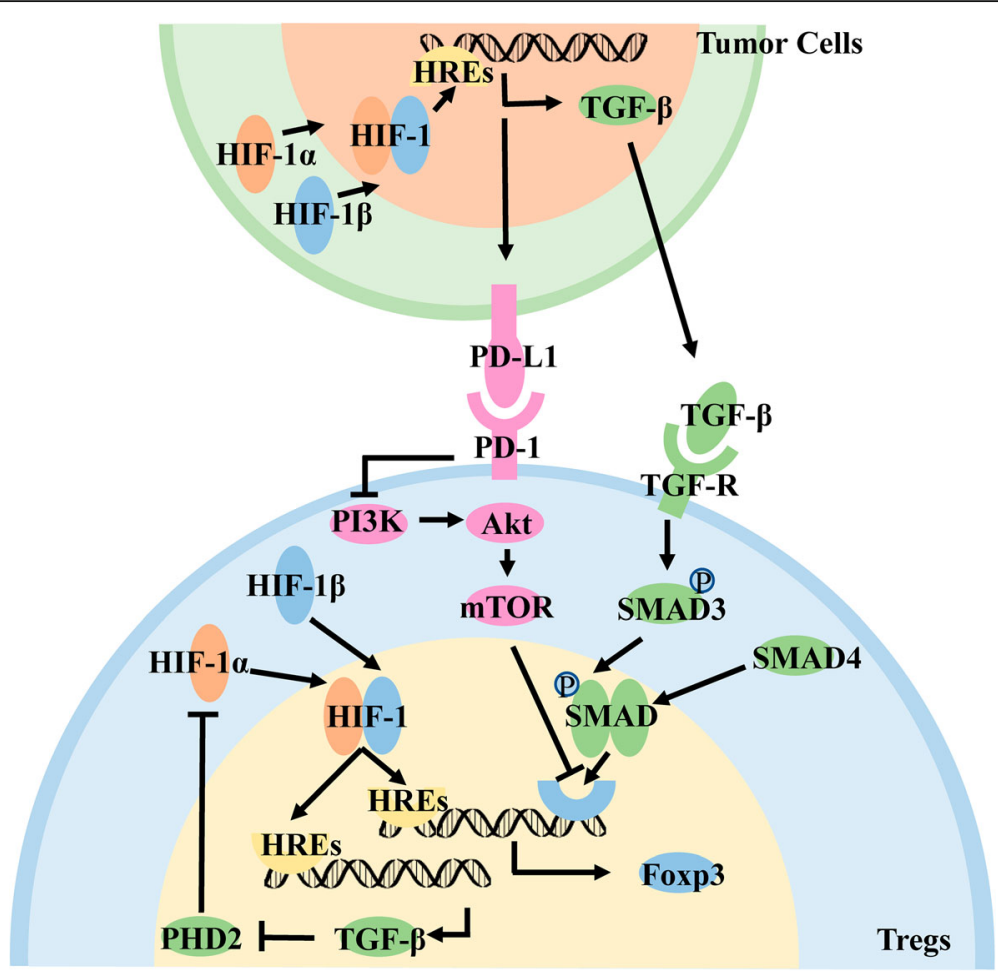

Fig. 6 Hypoxia induces differentiation of T-cells to Tregs. T cells directly promote the expression of Foxp3 through the HIF signaling pathway. T cells promote the expression of TGF- $\beta$ through HIF signaling, inhibit the key enzyme PHD2 for HIF-1a degradation, and indirectly promote the expression of Foxp3. Tumor cells promote the expression of TGF- $\beta$ through the HIF signaling pathway, act on the receptors on the surface of T cells, activate the downstream SMAD signaling pathway, and promote the expression of Foxp3.Tumor cells promote the expression of PD-L1 on the cell surface through the HIF signaling pathway, bind PD-1 on the surface of T cells, inhibit the downstream AKT and mTOR pathways, and promote the expression of Foxp3

downstream JAK/STAT5 signaling pathway by binding to the IL-2 receptor [117]. RA indirectly affects the quantity and function of infiltrating Tregs in tumor tissues. (Fig. 8).

\section{Conclusions}

Owing to their rapid proliferation and invasion and metastasis characteristics, tumor cells have large differences in their metabolic activities from normal cells. There are many cell types that infiltrate the microenvironment in which the tumor cells are located, including immune cells and mesenchymal cells [118]. Changes in metabolic activity and an increase in infiltrating cells lead to a change in the physicochemical properties of the tumor microenvironment, the most notable of which are hypoxia and $\mathrm{pH}$ reduction. Metabolic reprogramming and microenvironmental changes will cause changes in cell-associated transcription factors and secretory substances, which will affect the occurrence and development of tumors.

Tregs are $\mathrm{T}$ cells that suppress immunity and heavily infiltrate tumor tissues, regulating tumor proliferation, invasion, and metastasis. Metabolic reprogramming and microenvironmental changes generally play a role in promoting the function of Tregs: i) invasion of Tregs into tumor tissue by cytoskeletal rearrangement or secretion of chemokines; ii) induce of transcription factors or suppressive cytokines that promote the differentiation of T cells into Tregs; and iii) stimulation of the immunosuppressive function by regulating metabolism or promoting Treg secretion of functional cytokines. There are probably still chemokines, cytokines, and relevant signaling pathways to be discovered with the above modes of action. The effects of metabolism on Tregs are two-sided. Glycolysis can promote the proliferation of Tregs but it inhibits its immunosuppressive function. The metabolites of glycolysis can participate in other metabolic activities that promote Treg function. The effects of metabolic reprogramming on Tregs are not limited to the role of a single signaling pathway or a single type of metabolism. Instead, they are affected by changes in the microenvironment to regulate the cell function. The key transcription factor, HIF- $1 \alpha$, in the tumor microenvironment is also bidirectional in regulating Tregs. The expression of HIF- $1 \alpha$ is increased under hypoxia. On one hand, it can inhibit the differentiation of Tregs by 


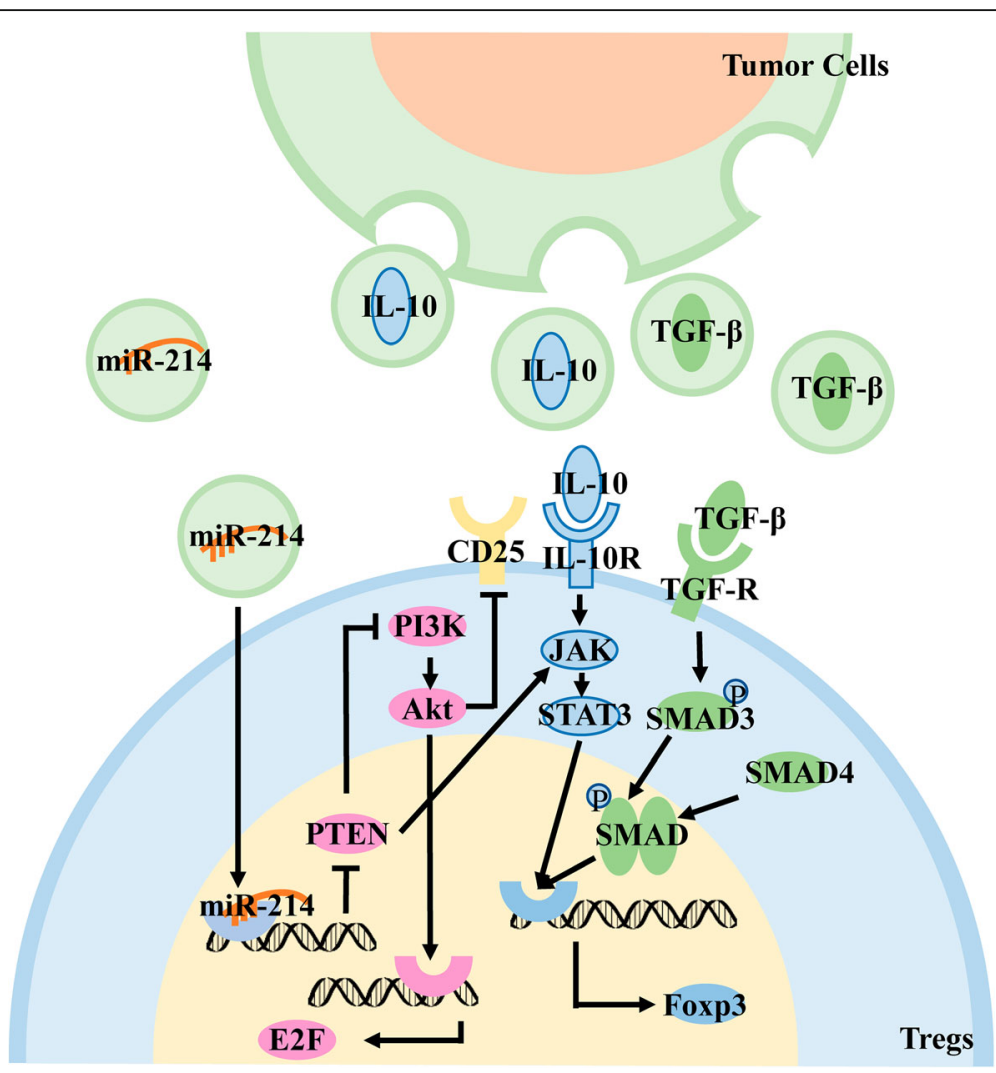

Fig. 7 Low pH induces differentiation of T cell into Tregs. Tumor-derived exosomes contain TGF- $\beta$, which acts on the receptor on the surface of T cells to activate the SMAD signaling pathway and promote the expression of Foxp3. Tumor-derived exosomes contain IL-10, which acts on receptors on the T cell surface to activate the JAK/STAT signaling pathways and promote Foxp3 expression. Tumor-derived exosomes contain miR-214, which enters Tregs by endocytosis, inhibits the expression of PTEN protein, and then promotes the expression of the cycle-related transcription factor E2F by activating the PI3K signaling pathway and promote Tregs proliferation. PTEN maintains the stability of Tregs by inhibiting the activation of PI3K JAkt to stabilize the expression of CD25 and promotes the induction of the JAK-STAT signaling pathway to maintains the stability of Tregs

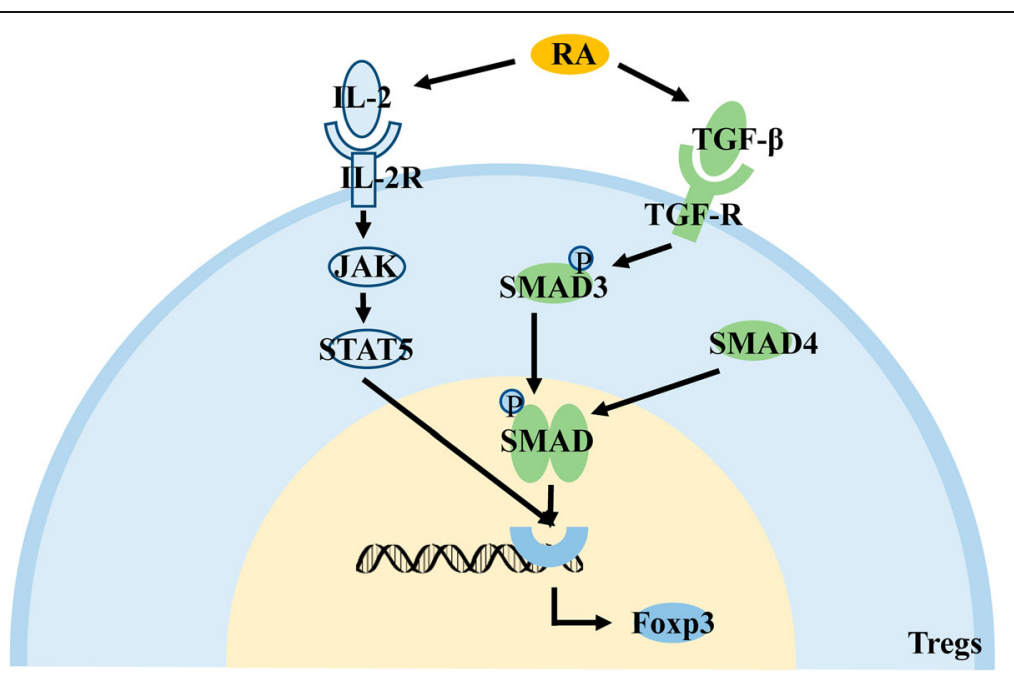

Fig. 8 Effects of the metabolite, RA, on Tregs. RA in the microenvironment promotes the expression of Foxp3 by promoting the activation of the downstream JAK/STAT5 signaling pathway by IL-2 and the activation of the downstream SMAD signaling pathway by TGF- $\beta$, indirectly promoting the differentiation and proliferation of Tregs 
promoting glycolysis $[119,120]$, and on the other hand, it can promote the expression of Foxp3 and promote the differentiation of Tregs. The above phenomenon may be due to the different means of regulating the expression level of HIF-1 $\alpha$ in cells. Different cytokines stimulates HIF- $1 \alpha$ to activate different downstream signaling pathways, which leads to different functions of regulatory $\mathrm{T}$ cells [120]. Intracellular feedback regulation also affects the function of HIF- $1 \alpha$. Tregs affects its function according to the stimulation and regulation inside and outside the cell. In addition to traditional methods of regulation, non-coding RNAs can also affect the function of Tregs. miRs can be secreted by cells in exosomes, and then modulate the Tregs to act on the corresponding target regulatory cells. There are many kinds of non-coding RNAs, and their mode of action is complex. Further research is necessary to explore these regulatory mechanisms of Treg function. Many of the above experiments were performed in vitro, failing to completely simulate the complex dynamic balance of the tumor microenvironment, and Tregs are susceptible to this microenvironment. The experimental results may be inconsistent with the in vivo experiments; therefore, it is necessary to continue the exploration with rigorous experiments.

In addition to surgical treatment, chemotherapy, and radiotherapy, immunotherapy has gained increasing attention, including treatment of PD-L1 and its related signaling pathways [121], inhibitors of CTLA-4 [122], and CAR-T treatment [123]. Tregs as major immunosuppressive cells have an important influence on the occurrence and development of tumors. Although large numbers of Tregs are usually associated with poor clinical outcomes, the role of Tregs in colorectal cancer [124], head and neck squamous cell carcinoma [125], and esophageal cancer [49] remains controversial. This may be a result of the presence of chronic inflammation in tumor tissue that promotes abnormal cell proliferation, angiogenesis, and distant metastasis [126], whereas Tregs act as immunosuppressive cells that inhibit tumor development by reducing chronic inflammation. In addition, Tregs can also be divided into different subtypes according to the expression levels of Foxp3 and CD45RA, and the prognosis of patients with colorectal cancer is closely related to the infiltrating Treg subtype [127]. The complex role of Tregs in tumor progression may also be affected by the tumor microenvironment. Changes in tumor microenvironment and metabolic reprogramming can affect not only the differentiation of primary $\mathrm{T}$ cells into Tregs, but also its immune suppression function, and therefore also the balance of Tregs and Th17 by affecting the expression of Foxp3 and RORgt [128, 129]. The above factors comprehensively affect tumor progression. Therapeutic methods targeting Tregs are also receiving increasing attention. However, directly killing the Tregs in the tumor tissue does not improve the patient's condition, because the adenosine produced by apoptotic Tregs will continue to inhibit the function of the effector cells [130]. Therefore, inhibiting the migration of Tregs to tumor tissues may have an effect on the treatment of cancer. Clinical trials have been conducted for treatment with chemokines, such as the use of monoclonal antibodies against CCR4 in the treatment of lymphoma, and a significant anti-tumor effect has been observed [131]. Regarding tumor infiltrating Tregs, Tregs can be depleted in tumor tissues by targeting the Treg surface-specific receptor, CD25, to inhibit tumor growth. Improving anti-CD25 antibodies and using them together with PD-1 antibodies may lead to a better therapeutic effect [132]. The fusion protein formed by IL-2 and diphtheria toxin can recognize IL-2R on the surface of Tregs to clear the cells. Treatment of renal cancer can effectively reduce the number of Tregs in the body, thereby achieving the purpose tumors treatments [133]. In addition to the expression of the transcription factor Foxp3, Tregs also expresses the transcription factor, Helios, to maintain stability. Deleting Helios will lead to the conversion of Tregs into effector $\mathrm{T}$ cells, which significantly delays tumor growth. Therefore, Helios targeting can be used as a feasible treatment strategy [134]. Similarly, targeting of Foxp3 can also help to regulate the expression of Tregs [135]. Moreover the treatment based on metabolic reprogramming has also been used in some immune diseases [136].

Based on the current status of immunotherapy, research still needs to be performed to improve our understanding of the mechanism of interaction between the tumor, Tregs and its subtypes, and other immune cells. Finding key cytokines, signaling pathways, noncoding RNAs that are relevant to Treg' function is needed, and these will serve as potential targets for immunotherapy. The present review, which highlights the changes in the tumor microenvironment that result in changes in metabolites and thus affect the function of Tregs, enriches the theoretical basis of tumor immunosuppression, and may provide new directions for cancer immunotherapy.

\section{Abbreviations}

AMPK: AMP kinase; CA: Carbonic anhydrase; CNS2: Non-coding sequence 2; CPT1A: Carnitine palmitoyltransferase-1A; CTLA: Cytotoxic T lymphocyteassociated antigen; FAO: Fatty acid oxidation; Foxp3: Forkhead/flanking helix nuclear transcription factor; GCK: Glucokinase; HIF: hypoxia-inducible factor; HRES: Hypoxia response elements; IDO: Indoleamine 2,3 dioxygenase;

IL: Interleukin; LDH-A: Lactate dehydrogenase A; MCT: Monocarboxylate transporter; miRs: microRNAs; NFAT: Nuclear factor of activated T cells;

OXPHOS: Oxidative phosphorylation; PD-1: Programmed cell death protein-1; 
PD-L1: Programmed death-ligand-1; RA: Retinoic acid; ROS: Reactive oxygen species; TGF: Transforming growth factor; TLR: Toll-like receptora; Tregs: Regulatory T cells; VEGF: Vascular endothelial growth factor

\section{Acknowledgements}

Not applicable.

\section{Funding}

This work was supported in part by grants from the National Natural Science Foundation of China (81572787, 81672683, 81672993, 81772928, 81702907 and 81772901), the Overseas Expertise Introduction Project for Discipline Innovation (111 Project, No. 111-2-12), the Natural Science Foundation of Hunan Province (2016JC2035, 2017SK2105, 2018JJ3815, 2018JJ3704, 2018SK21210 and 2018SK21211), Central South University Graduate Research and Innovation Project (2018zzts080, 2018zzts828), and Mittal Student Innovation Program(201810533271).

\section{Availability of data and materials}

Not applicable.

\section{Authors' contributions}

$Y W, X L, Y M$ collected the related paper and drafted the manuscript. CF, LT, $F X, C G, B X, M Z, J M, X H, X W, Y L, G L, Z Z$ and $W X$ participated in the design of the review and draft the manuscript. All authors read and approved the final manuscript.

\section{Ethics approval and consent to participate}

Not applicable.

\section{Consent for publication}

Not applicable.

\section{Competing interests}

The authors declare that they have no competing interests.

\section{Publisher's Note}

Springer Nature remains neutral with regard to jurisdictional claims in published maps and institutional affiliations.

\footnotetext{
Author details

'The Key Laboratory of Carcinogenesis of the Chinese Ministry of Health, Hunan Cancer Hospital and The Affiliated Cancer Hospital of Xiangya School of Medicine, Central South University, Changsha 410013, Hunan, China. ${ }^{2}$ The Key Laboratory of Carcinogenesis and Cancer Invasion of the Chinese Ministry of Education, Cancer Research Institute and School of Basic Medical Science, Xiangya School of Medicine, Central South University, Changsha 410078, China. ${ }^{3}$ Department of Molecular Genetics, University of Toronto, Toronto, ON M5S 1A8, Canada. ${ }^{4}$ Department of Chemistry, University of North Dakota, Grand Forks, North Dakota 58202, USA. ${ }^{5}$ Department of Cancer Biology, Lerner Research Institute, Cleveland Clinic, Cleveland, OH 44195, USA.

Received: 8 August 2018 Accepted: 6 November 2018

Published online: 26 November 2018

\section{References}

1. Wei F, Wu Y, Tang L, Xiong F, Guo C, Li X, Zhou M, Xiang B, Li X, Li G, et al. Trend analysis of cancer incidence and mortality in China. Sci China Life Sci. 2017;60(11):1271-5.

2. Hanahan D, Weinberg RA. Hallmarks of cancer: the next generation. Cell. 2011;144(5):646-74.

3. Tu C, Zeng Z, Qi P, Li X, Guo C, Xiong F, Xiang B, Zhou M, Liao Q, Yu J, et al. Identification of genomic alterations in nasopharyngeal carcinoma and nasopharyngeal carcinoma-derived Epstein-Barr virus by whole genome sequencing. Carcinogenesis. 2018; https://doi.org/10.1093/carcin/bgy108.

4. Zou G, Ren B, Liu Y, Fu Y, Chen P, Li X, Luo S, He J, Gao G, Zeng Z, et al. INHBB suppresses anoikis resistance and migration through TGF-beta signaling pathway in nasopharyngeal carcinoma. Cancer Sci. 2018;109(11): $3416-27$.
}

5. Tang Y, He Y, Zhang P, Wang J, Fan C, Yang L, Xiong F, Zhang S, Gong Z, Nie $S$, et al. LncRNAs regulate the cytoskeleton and related rho/ROCK signaling in cancer metastasis. Mol Cancer. 2018;17(1):77.

6. Wei F, Tang L, He Y, Wu Y, Shi L, Xiong F, Gong Z, Guo C, Li X, Liao Q, et al. BPIFB1 (LPLUNC1) inhibits radioresistance in nasopharyngeal carcinoma by inhibiting VTN expression. Cell Death Dis. 2018;9(4):432.

7. Yang L, Tang Y, Xiong F, He Y, Wei F, Zhang S, Guo C, Xiang B, Zhou M, Xie $\mathrm{N}$, et al. LncRNAs regulate cancer metastasis via binding to functional proteins. Oncotarget. 2017;9(1):1426-43.

8. Wei F, Wu Y, Tang L, He Y, Shi L, Xiong F, Gong Z, Guo C, Li X, Liao Q, et al. BPIFB1 (LPLUNC1) inhibits migration and invasion of nasopharyngeal carcinoma by interacting with VTN and VIM. Br J Cancer. 2018;1 18(2):233-47.

9. Tang Y, Wang J, Lian Y, Fan C, Zhang P, Wu Y, Li X, Xiong F, Li X, Li G, et al. Linking long non-coding RNAs and SWI/SNF complexes to chromatin remodeling in cancer. Mol Cancer. 2017;16(1):42.

10. He B, Li W, Wu Y, Wei F, Gong Z, Bo H, Wang Y, Li X, Xiang B, Guo C, et al. Epstein-Barr virus-encoded miR-BART6-3p inhibits cancer cell metastasis and invasion by targeting long non-coding RNA LOC553103. Cell Death Dis. 2016;7(9):e2353.

11. Zhong Y, Du Y, Yang X, Mo Y, Fan C, Xiong F, Ren D, Ye X, Li C, Wang Y, et al. Circular RNAs function as ceRNAs to regulate and control human cancer progression. Mol Cancer. 2018;17(1):79.

12. Zhou R, Wu Y, Wang W, Su W, Liu Y, Wang Y, Fan C, Li X, Li G, Li Y, et al. Circular RNAs (circRNAs) in cancer. Cancer Lett. 2018;425:134-42.

13. Yu J, Liu Y, Gong Z, Zhang S, Guo C, Li X, Tang Y, Yang L, He Y, Wei F, et al. Overexpression long non-coding RNA LINC00673 is associated with poor prognosis and promotes invasion and metastasis in tongue squamous cell carcinoma. Oncotarget. 2017;8(10):16621-32.

14. Wang M, Zhao J, Zhang L, Wei F, Lian Y, Wu Y, Gong Z, Zhang S, Zhou J, Cao K, et al. Role of tumor microenvironment in tumorigenesis. J Cancer. 2017;8(5):761-73.

15. Chen S, Zheng P, Wang W, Yi M, Chen P, Cai J, Li J, Peng Q, Ban Y, Zhou Y, et al. Abberent expression of NOR1 protein in tumor associated macrophages contributes to the development of DEN-induced hepatocellular carcinoma. J Cell Physiol. 2018;233(6):5002-13.

16. Fan C, Tang Y, Wang J, Xiong F, Guo C, Wang Y, Xiang B, Zhou M, Li X, Wu $X$, et al. The emerging role of Epstein-Barr virus encoded microRNAs in nasopharyngeal carcinoma. J Cancer. 2018;9(16):2852-64.

17. Yi M, Cai J, Li J, Chen S, Zeng Z, Peng Q, Ban Y, Zhou Y, Li X, Xiong W, et al. Rediscovery of NF-kappaB signaling in nasopharyngeal carcinoma: how genetic defects of NF-kappaB pathway interplay with EBV in driving oncogenesis? J Cell Physiol. 2018;233(8):5537-49.

18. Tang Y, He Y, Shi L, Yang L, Wang J, Lian Y, Fan C, Zhang P, Guo C, Zhang $\mathrm{S}$, et al. Co-expression of AFAP1-AS1 and PD-1 predicts poor prognosis in nasopharyngeal carcinoma. Oncotarget. 2017;8(24):39001-11.

19. Wang JP, Tang YY, Fan CM, Guo C, Zhou YH, Li Z, Li XL, Li Y, Li GY, Xiong W et al. The role of exosomal non-coding RNAs in cancer metastasis. Oncotarget. 2017;9(15):12487-502.

20. Tang L, Wei F, Wu Y, He Y, Shi L, Xiong F, Gong Z, Guo C, Li X, Deng H, et al. Role of metabolism in cancer cell radioresistance and radiosensitization methods. J Exp Clin Cancer Res. 2018;37(1):87.

21. Wang W, Yi M, Zhang R, Li J, Chen S, Cai J, Zeng Z, Li X, Xiong W, Wang L, et al. Vimentin is a crucial target for anti-metastasis therapy of nasopharyngeal carcinoma. Mol Cell Biochem. 2018:438(1-2):47-57.

22. Zhang Y, Xia M, Jin K, Wang S, Wei H, Fan C, Wu Y, Li X, Li X, Li G, et al. Function of the c-met receptor tyrosine kinase in carcinogenesis and associated therapeutic opportunities. Mol Cancer. 2018;17(1):45.

23. Tu C, Zeng Z, Qi P, Li X, Yu Z, Guo C, Xiong F, Xiang B, Zhou M, Gong Z, et al. Genome-Wide Analysis of 18 Epstein-Barr Viruses Isolated from Primary Nasopharyngeal Carcinoma Biopsy Specimens. J Virol. 2017;91(17):e00301-17.

24. Folkman J. Fundamental concepts of the angiogenic process. Current Molecular Medicine. 2003;3(7):643-51.

25. Kim Y, Nam HJ, Lee J, Park DY, Kim C, Yu YS, Kim D, Park SW, Bhin J, Hwang $\mathrm{D}$, et al. Methylation-dependent regulation of HIF-1alpha stability restricts retinal and tumour angiogenesis. Nat Commun. 2016;7:10347.

26. Hida K, Maishi N, Torii C, Hida Y. Tumor angiogenesis--characteristics of tumor endothelial cells. Int J Clin Oncol. 2016;21(2):206-12.

27. Warburg O, Wind F, Negelein E. The Metabolism of Tumors in the Body. J Gen Physiol. 1926;8(6):519-30.

28. Yi M, Li J, Chen S, Cai J, Ban Y, Peng Q, Zhou Y, Zeng Z, Peng S, Li X, et al. Emerging role of lipid metabolism alterations in Cancer stem cells. J Exp Clin Cancer Res. 2018;37(1):118. 
29. Marín-Hernández A, Gallardo-Pérez JC, Ralph SJ, Rodríguez-Enríquez S, Moreno-Sánchez R. HIF-1alpha modulates energy metabolism in cancer cells by inducing over-expression of specific glycolytic isoforms. Mini Rev Med Chem. 2009;9(9):1084-101.

30. Shim H, Dolde C, Lewis BC, Wu CS, Dang G, Jungmann RA, Dalla-Favera R, Dang CV. C-Myc transactivation of LDH-A: implications for tumor metabolism and growth. Proc Natl Acad Sci USA. 1997;94(13):6658-63.

31. Baltazar F, Pinheiro C, Morais-Santos F, Azevedo-Silva J, Queirós O, Preto A, Casal M. Monocarboxylate transporters as targets and mediators in cancer therapy response. Histol Histopathol. 2014;29(12):1511-24.

32. Lou Y, McDonald PC, Oloumi A, Chia S, Ostlund C, Ahmadi A, Kyle A, Auf dem Keller U, Leung S, Huntsman D, et al. Targeting tumor hypoxia: suppression of breast tumor growth and metastasis by novel carbonic anhydrase IX inhibitors. Cancer Res. 2011;71(9):3364-76.

33. Stock C, Cardone RA, Busco G, Krähling H, Schwab A, Reshkin SJ. Protons extruded by NHE1: digestive or glue? Eur J Cell Biol. 2008;87(8-9):591-9.

34. Hilvo M, Orešič AM. Regulation of lipid metabolism in breast cancer provides diagnostic and therapeutic opportunities. Clin Lipidol. 2012;7(2):177-88.

35. Schulze A, Harris AL. How cancer metabolism is tuned for proliferation and vulnerable to disruption. Nature. 2012;491(7424):364-73.

36. Son J, Lyssiotis CA, Ying H, Wang X, Hua S, Ligorio M, Perera RM, Ferrone CR, Mullarky E, Shyh-Chang N, et al. Glutamine supports pancreatic cancer growth through a KRAS-regulated metabolic pathway. Nature. 2013;496(7443):101-5.

37. Amelio I, Cutruzzolá F, Antonov A, Agostini M, Melino G. Serine and glycine metabolism in cancer. Trends Biochem Sci. 2014;39(4):191-8.

38. Payen VL, Porporato PE, Baselet B, Sonveaux P. Metabolic changes associated with tumor metastasis, part 1: tumor $\mathrm{pH}$, glycolysis and the pentose phosphate pathway. Cell Mol Life Sci. 2016;73(7):1333-48.

39. Porporato PE, Payen VL, Baselet $B$, Sonveaux P. Metabolic changes associated with tumor metastasis, part 2: mitochondria, lipid and amino acid metabolism. Cell Mol Life Sci. 2016;73(7):1349-63.

40. He R, Liu P, Xie X, Zhou Y, Liao Q, Xiong W, Li X, Li G, Zeng Z, Tang H. circGFRA1 and GFRA1 act as ceRNAs in triple negative breast cancer by regulating miR-34a. J Exp Clin Cancer Res. 2017;36(1):145.

41. Fan C, Tang Y, Wang J, Xiong F, Guo C, Wang Y, Zhang S, Gong Z, Wei F, Yang $\mathrm{L}$, et al. Role of long non-coding RNAs in glucose metabolism in cancer. Mol Cancer. 2017;16(1):130.

42. Li Q, Chen P, Zeng Z, Liang F, Song Y, Xiong F, Li X, Gong Z, Zhou M, Xiang $B$, et al. Yeast two-hybrid screening identified WDR77 as a novel interacting partner of TSC22D2. Tumour Biol. 2016;37(9):12503-12.

43. Liang F, Li Q, Li X, Li Z, Gong Z, Deng H, Xiang B, Zhou M, Li X, Li G, et al. TSC22D2 interacts with PKM2 and inhibits cell growth in colorectal cancer. Int J Oncol. 2016;49(3):1046-56.

44. He $Y$, Jing $Y$, Wei F, Tang $Y$, Yang L, Luo J, Yang P, Ni Q, Pang J, Liao Q, et al. Long non-coding RNA PVT1 predicts poor prognosis and induces radioresistance by regulating DNA repair and cell apoptosis in nasopharyngeal carcinoma. Cell Death Dis. 2018;9(2):235.

45. Martin Villalba MGR, Lopez-Royuela N, Krzywinska E, Garaude J, AllendeVega N. From tumor cell metabolism to tumor immune escape. International Journal of Biochemistry \& Cell Biology. 2013;45(1):106-13.

46. Bhatia A, Kumar Y. Cellular and molecular mechanisms in cancer immune escape: a comprehensive review. Expert Rev Clin Immunol. 2014;10(1):41-62.

47. Shevach EM. Foxp3(+) T regulatory cells: still many unanswered questions-a perspective after 20 years of study. Front Immunol. 2018;9:1048.

48. Wang J, Ke XY. The four types of Tregs in malignant lymphomas. J Hematol Oncol. 2011:4:50

49. Shang B, Liu Y, Jiang SJ, Liu Y. Prognostic value of tumor-infiltrating FoxP3+ regulatory $T$ cells in cancers: a systematic review and meta-analysis. Sci Rep. 2015;5:15179.

50. Yu P, Lee Y, Liu W, Krausz T, Chong A, Schreiber H, Fu YX. Intratumor depletion of CD4+ cells unmasks tumor immunogenicity leading to the rejection of late-stage tumors. J Exp Med. 2005;201(5):779-91.

51. Marabelle A, Kohrt H, Sagiv-Barfi I, Ajami B, Axtell RC, Zhou G, Rajapaksa R, Green MR, Torchia J, Brody J, et al. Depleting tumor-specific Tregs at a single site eradicates disseminated tumors. J Clin Invest. 2013;123(6):2447-63.

52. Shimizu J, Yamazaki S, Sakaguchi S. Induction of Tumor Immunity by Removing CD251CD41 T Cells A Common Basis Between Tumor Immunity and Autoimmunity. J Immunol. 1999;163(10):5211-8.

53. Onizuka S, Tawara I, Shimizu J, Sakaguchi S, Fujita T, Nakayama E. Tumor Rejection by in Vivo Administration of Anti-CD25 (Interleukin-2 Receptor a) Monoclonal Antibody. Cancer Res. 1999:59(13):3128-33.
54. Yoshie O, Matsushima K. CCR4 and its ligands: from bench to bedside. Int Immunol. 2015;27(1):11-20.

55. Yamazaki S, lyoda T, Tarbell K, Olson K, Velinzon K, Inaba K, Steinman RM. Direct expansion of functional CD25+ CD4+ regulatory T cells by antigenprocessing dendritic cells. J Exp Med. 2003;198(2):235-47.

56. Qiu B, Zhang D, Wang C, Tao J, Tie X, Qiao Y, Xu K, Wang Y, Wu A. IL-10 and TGF-beta2 are overexpressed in tumor spheres cultured from human gliomas. Mol Biol Rep. 2011;38(5):3585-91.

57. Chen J, Ye Y, Liu P, Yu W, Wei F, Li H, Yu J. Suppression of T cells by myeloid-derived suppressor cells in cancer. Hum Immunol. 2017;78(2):113-9.

58. Sakaguchi S, Sakaguchi N, Asano M, Itoh M, Toda M. Immunologic selftolerance maintained by activated $T$ cells expressing IL-2 receptor alphachains (CD25). Breakdown of a single mechanism of self-tolerance causes various autoimmune diseases. J Immunol. 1995;115(3):1151-64.

59. Curotto de Lafaille MA, Lafaille JJ. Natural and adaptive foxp3+ regulatory T cells: more of the same or a division of labor? Immunity. 2009;30(5):626-35.

60. Lourenco EV, La Cava A. Natural regulatory T cells in autoimmunity. Autoimmunity. 2011;44(1):33-42.

61. Li B, Greene MI. Special regulatory T-cell review: FOXP3 biochemistry in regulatory $T$ cells--how diverse signals regulate suppression. Immunology. 2008;123(1):17-9.

62. Fontenot JD, Gavin MA, Rudensky AY. Foxp3 programs the development and function of CD4+CD25+ regulatory T cells. Nat Immunol. 2003;4(4):330-6.

63. Morikawa H, Ohkura N, Vandenbon A, Itoh M, Nagao-Sato S, Kawaji H, Lassmann T, Carninci P, Hayashizaki Y, Forrest AR, et al. Differential roles of epigenetic changes and Foxp3 expression in regulatory T cell-specific transcriptional regulation. Proc Natl Acad Sci USA. 2014;111(14):5289-94.

64. Plitas G, Rudensky AY. Regulatory T cells: differentiation and function. Cancer Immunol Res. 2016;4(9):721-5.

65. van der Veeken J, Arvey A, Rudensky A. Transcriptional control of regulatory T-cell differentiation. Cold Spring Harb Symp Quant Biol. 2013;78:215-22.

66. Cao X, Cai SF, Fehniger TA, Song J, Collins LI, Piwnica-Worms DR, Ley TJ. Granzyme B and perforin are important for regulatory $T$ cell-mediated suppression of tumor clearance. Immunity. 2007;27(4):635-46.

67. Vignali DA, Collison LW, Workman CJ. How regulatory T cells work. Nat Rev Immunol. 2008;8(7):523-32.

68. Walker LS. Treg and CTLA-4: two intertwining pathways to immune tolerance. J Autoimmun. 2013;45:49-57.

69. Fallarino F, Grohmann U, Hwang KW, Orabona C, Vacca C, Bianchi R, Belladonna ML, Fioretti MC, Alegre ML, Puccetti P. Modulation of tryptophan catabolism by regulatory T cells. Nat Immunol. 2003;4(12):1206-12.

70. Wang H, Franco F, Ho PC. Metabolic regulation of Tregs in Cancer: opportunities for immunotherapy. Trends Cancer. 2017;3(8):583-92.

71. Jang JE, Hajdu CH, Liot C, Miller G, Dustin ML, Bar-Sagi D. Crosstalk between regulatory $T$ cells and tumor-associated dendritic cells negates anti-tumor immunity in pancreatic Cancer. Cell Rep. 2017;20(3):558-71.

72. Hutloff A, Dittrich AM, Beier KC, Eljaschewitsch B, Kraft R, Anagnostopoulos I, Kroczek RA. ICOS is an inducible T-cell co-stimulator structurally and functionally related to CD28. Nature. 1999;397(6716):263-6.

73. de Jong YP, Rietdijk ST, Faubion WA, Abadia-Molina AC, Clarke K, Mizoguchi E, Tian J, Delaney T, Manning S, Gutierrez-Ramos JC, et al. Blocking inducible co-stimulator in the absence of CD28 impairs Th1 and CD25+ regulatory $T$ cells in murine colitis. Int Immunol. 2004;16(2):205-13.

74. Deaglio S, Dwyer KM, Gao W, Friedman D, Usheva A, Erat A, Chen JF, Enjyoji K, Linden J, Oukka M, et al. Adenosine generation catalyzed by CD39 and CD73 expressed on regulatory T cells mediates immune suppression. J Exp Med. 2007;204(6):1257-65.

75. Kishore M, Cheung KCP, Fu H, Bonacina F, Wang G, Coe D, Ward EJ, Colamatteo A, Jangani M, Baragetti A, et al. Regulatory T cell migration is dependent on Glucokinase-mediated glycolysis. Immunity. 2017;47(5):875-89.e10

76. Gerriets VA, Kishton RJ, Johnson MO, Cohen S, Siska PJ, Nichols AG, Warmoes MO, de Cubas AA, Maclver NJ, Locasale JW, et al. Foxp3 and tolllike receptor signaling balance Treg cell anabolic metabolism for suppression. Nat Immunol. 2016;17(12):1459-66.

77. Newton RH, Turka LA. Regulation of T cell homeostasis and responses by pten. Front Immunol. 2012;3:151.

78. Ouyang W, Liao W, Luo CT, Yin N, Huse M, Kim MV, Peng M, Chan P, Ma Q, Mo $Y$, et al. Novel Foxo1-dependent transcriptional programs control Treg cell function. Nature. 2012;491(7425):554-9. 
79. Kerdiles YM, Stone EL, Beisner DR, McGargill MA, Ch'en IL, Stockmann C, Katayama CD, Hedrick SM. Foxo transcription factors control regulatory $T$ cell development and function. Immunity. 2010;33(6):890-904.

80. Angelin A, Gil-de-Gómez L, Dahiya S, Jiao J, Guo L, Levine MH, Wang Z, Quinn WJ 3rd, Kopinski PK, Wang $L$, et al. Foxp3 reprograms T cell metabolism to function in low-glucose, High-Lactate Environments. Cell Metab. 2017;25(6):1282-93.e7.

81. Wang R, Dillon CP, Shi LZ, Milasta S, Carter R, Finkelstein D, McCormick LL, Fitzgerald P, Chi H, Munger J, et al. The transcription factor Myc controls metabolic reprogramming upon T lymphocyte activation. Immunity. 2011;35(6):871-82.

82. Coe DJ, Kishore M, Marelli-Berg F. Metabolic regulation of regulatory T cell development and function. Front Immunol. 2014;5:590.

83. Michalek RD, Gerriets VA, Jacobs SR, Macintyre AN, Maclver NJ, Mason EF, Sullivan SA, Nichols AG, Rathmell JC. Cutting edge: distinct glycolytic and lipid oxidative metabolic programs are essential for effector and regulatory CD4+ T cell subsets. J Immunol. 2011;186(6):3299-03.

84. Patsoukis N, Bardhan K, Chatterjee P, Sari D, Liu B, Bell LN, Karoly ED, Freeman GJ, Petkova V, Seth P, et al. PD-1 alters T-cell metabolic reprogramming by inhibiting glycolysis and promoting lipolysis and fatty acid oxidation. Nat Commun. 2015;6:6692.

85. Howie D, Cobbold SP, Adams E, Ten Bokum A, Necula AS, Zhang W, Huang H, Roberts DJ, Thomas B, Hester SS, et al. Foxp3 drives oxidative phosphorylation and protection from lipotoxicity. JCI Insight. 2017;2(3):e89160.

86. Sena LA, Li S, Jairaman A, Prakriya M, Ezponda T, Hildeman DA, Wang CR,

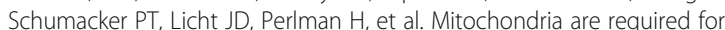
antigen-specific $\mathrm{T}$ cell activation through reactive oxygen species signaling. Immunity. 2013;38(2):225-36.

87. Li X, Liang Y, LeBlanc M, Benner C, Zheng Y. Function of a Foxp3 ciselement in protecting regulatory T cell identity. Cell. 2014;158(4):734-48.

88. Jiang BH, Semenza GL, Bauer C, Marti HH. Hypoxia-inducible factor 1 levels vary exponentially over a physiologically relevant range of $\mathrm{O} 2$ tension. Am J Physiol. 1996;271(4 Pt 1):C1172-80.

89. Majmundar AJ, Wong WJ, Simon MC. Hypoxia-inducible factors and the response to hypoxic stress. Mol Cell. 2010;40(2):294-309.

90. Kaluz S, Kaluzova M, Stanbridge EJ. Regulation of gene expression by hypoxia: integration of the HIF-transduced hypoxic signal at the hypoxiaresponsive element. Clin Chim Acta. 2008;395(1-2):6-13.

91. Parolini I, Federici C, Raggi C, Lugini L, Palleschi S, De Milito A, Coscia C, lessi E, Logozzi M, Molinari A, et al. Microenvironmental $\mathrm{pH}$ is a key factor for exosome traffic in tumor cells. J Biol Chem. 2009;284(49):34211-22.

92. Schorey JS, Bhatnagar S. Exosome function: from tumor immunology to pathogen biology. Traffic. 2008;9(6):871-81.

93. King HW, Michael MZ, Gleadle JM. Hypoxic enhancement of exosome release by breast cancer cells. BMC Cancer. 2012;12:421.

94. Facciabene A, Peng X, Hagemann IS, Balint K, Barchetti A, Wang LP, Gimotty PA, Gilks CB, Lal P, Zhang L,et al. Tumour hypoxia promotes tolerance and angiogenesis via CCL28 and T(reg) cells. Nature. 2011;475(7355):226-30.

95. Ren L, Yu Y, Wang L, Zhu Z, Lu R, Yao Z. Hypoxia-induced CCL28 promotes recruitment of regulatory $T$ cells and tumor growth in liver cancer. Oncotarget. 2016;7(46):75763-73.

96. Yan M, Jene N, Byrne D, Millar EK, O'Toole SA, McNeil CM, Bates GJ, Harris AL, Banham AH, Sutherland RL, et al. Recruitment of regulatory $T$ cells is correlated with hypoxia-induced CXCR4 expression, and is associated with poor prognosis in basal-like breast cancers. Breast Cancer Res. 2011;13(2):R47.

97. Wei S, Kryczek I, Edwards RP, Zou L, Szeliga W, Banerjee M, Cost M, Cheng $P$, Chang A, Redman B, et al. Interleukin-2 administration alters the CD4 +FOXP3+ T-cell pool and tumor trafficking in patients with ovarian carcinoma. Cancer Res. 2007;67(15):7487-94.

98. Wald O, Izhar U, Amir G, Avniel S, Bar-Shavit Y, Wald H, Weiss ID, Galun E, Peled A. CD4+CXCR4highCD69+ T cells accumulate in lung adenocarcinoma. J Immunol. 2006;177(10):6983-90.

99. Shimizu Y, Dobashi K, Imai H, Sunaga N, Ono A, Sano T, Hikino T, Shimizu K, Tanaka S, Ishizuka T, et al.CXCR4+FOXP3+CD25+ lymphocytes accumulate in CXCL12-expressing malignant pleural mesothelioma. Int J Immunopathol Pharmacol. 2009;22(1):43-51.

100. Mrizak D, Martin N, Barjon C, Jimenez-Pailhes AS, Mustapha R, Niki T, Guigay J, Pancré $V$, de Launoit $Y$, Busson $P$, et al. Effect of nasopharyngeal carcinoma-derived exosomes on human regulatory T cells. J Natl Cancer Inst. 2014;107(1):363.

101. Ben-Shoshan J, Maysel-Auslender S, Mor A, Keren G, George J. Hypoxia controls CD4+CD25+ regulatory T-cell homeostasis via hypoxia-inducible factor-1alpha. Eur J Immunol. 2008;38(9):2412-8.
102. Wu J, Cui H, Zhu Z, Wang L, Li H, Wang D. Effect of HIF1alpha on Foxp3 expression in CD4+ CD25- T lymphocytes. Microbiol Immunol. 2014;58(7): 409-15.

103. Clambey ET, McNamee EN, Westrich JA, Glover LE, Campbell EL, Jedlicka P, de Zoeten EF, Cambier JC, Stenmark KR, Colgan SP, et al. Hypoxia-inducible factor-1 alpha-dependent induction of FoxP3 drives regulatory T-cell abundance and function during inflammatory hypoxia of the mucosa. Proc Natl Acad Sci USA. 2012;109(41):E2784-93.

104. Fong GH, Takeda K. Role and regulation of prolyl hydroxylase domain proteins. Cell Death Differ. 2008;15(4):635-41.

105. Deng B, Zhu JM, Wang Y, Liu TT, Ding YB, Xiao WM, Lu GT, Bo P, Shen XZ Intratumor hypoxia promotes immune tolerance by inducing regulatory $T$ cells via TGF-beta1 in gastric cancer. PLoS One. 2013;8(5):e63777.

106. Chen J, Jiang CC, Jin L, Zhang XD. Regulation of PD-L1: a novel role of prosurvival signalling in cancer. Ann Oncol. 2016;27(3):409-16.

107. Ruf M, Moch H, Schraml P. PD-L1 expression is regulated by hypoxia inducible factor in clear cell renal cell carcinoma. Int J Cancer. 2016; 139(2):396-403.

108. Yamada N, Kuranaga Y, Kumazaki M, Shinohara H, Taniguchi K, Akao Y. Colorectal cancer cell-derived extracellular vesicles induce phenotypic alteration of T cells into tumor-growth supporting cells with transforming growth factor- $\beta 1$-mediated suppression. Oncotarget. 2016;7(19):27033-43.

109. Huber V, Fais $S$, lero $M$, Lugini $L$, Canese $P$, Squarcina $P$, Zaccheddu $A$ Colone M, Arancia G, Gentile M, et al. Human colorectal Cancer cells induce T-cell death through release of Proapoptotic microvesicles: role in immune escape. Gastroenterology. 2005;128(7):1796-804

110. Szajnik M1, Czystowska M, Szczepanski MJ, Mandapathil M, Whiteside TL. Tumor-derived microvesicles induce, expand and up-regulate biological activities of human regulatory T cells (Treg). PLoS One. 2010;5(7):e11469.

111. Yin Y, Cai X, Chen X, Liang H, Zhang Y, Li J, Wang Z, Chen X, Zhang W, Yokoyama $S$, et al. Tumor-secreted miR-214 induces regulatory $T$ cells: a major link between immune evasion and tumor growth. Cell Res. 2014; 24(10):1164-80.

112. Brennan P1, Babbage JW, Burgering BM, Groner B, Reif $K$, Cantrell DA. Phosphatidylinositol 3-Kinase Couples the Interleukin-2 Receptor to the Cell Cycle Regulator E2F. Immunity. 1997;7(5):679-89.

113. Huynh A, DuPage M, Priyadharshini B, Sage PT, Quiros J, Borges CM, Townamchai N, Gerriets VA, Rathmell JC, Sharpe AH, et al. Control of PI(3) kinase in Treg cells maintains homeostasis and lineage stability. Nat Immunol. 2015;16(2):188-96.

114. Bensinger SJ, Walsh PT, Zhang J, Carroll M, Parsons R, Rathmell JC, Thompson CB, Burchill MA, Farrar MA, Turka LA. Distinct IL-2 Receptor Signaling Pattern in CD4+CD25+ Regulatory T Cells. J Immunol. 2004;172(9): 5287-96.

115. Iwata M, Hirakiyama A, Eshima Y, Kagechika H, Kato C, Song SY. Retinoic acid imprints gut-homing specificity on T cells. Immunity. 2004;21(4):527-38.

116. Liu ZM, Wang KP, Ma J, Guo Zheng S. The role of all-trans retinoic acid in the biology of Foxp3+ regulatory T cells. Cell Mol Immunol. 2015; 12(5):553-7.

117. Zorn E, Nelson EA, Mohseni M, Porcheray F, Kim H, Litsa D, Bellucci R, Raderschall E, Canning C, Soiffer RJ, et al. IL-2 regulates FOXP3 expression in human CD4+CD25+ regulatory T cells through a STAT-dependent mechanism and induces the expansion of these cells in vivo. Blood. 2006; 108(5):1571-9.

118. Smith HA, Kang Y. The metastasis-promoting roles of tumor-associated immune cells. J Mol Med (Berl). 2013;91(4):411-29.

119. Shi LZ, Wang R, Huang G, Vogel P, Neale G, Green DR, Chi H. HIF1alphadependent glycolytic pathway orchestrates a metabolic checkpoint for the differentiation of TH17 and Treg cells. J Exp Med. 2011;208(7):1367-76.

120. Dang EV, Barbi J, Yang HY, Jinasena D, Yu H, Zheng Y, Bordman Z, Fu J, Kim $\mathrm{Y}$, Yen HR, et al. Control of $\mathrm{T}(\mathrm{H}) 17 / \mathrm{T}(\mathrm{reg})$ balance by hypoxia-inducible factor 1. Cell. 2011;146(5):772-84.

121. Sun C, Mezzadra R, Schumacher TN. Regulation and function of the PD-L1 checkpoint. Immunity. 2018;48(3):434-52.

122. Peggs KS, Quezada SA, Korman AJ, Allison JP. Principles and use of antiCTLA4 antibody in human cancer immunotherapy. Curr Opin Immunol. 2006;18(2):206-13.

123. Park TS, Rosenberg SA, Morgan RA. Treating cancer with genetically engineered T cells. Trends Biotechnol. 2011;29(11):550-7.

124. Zhuo C, Xu Y, Ying M, Li Q, Huang L, Li D, Cai S, Li B. FOXP3+ Tregs: heterogeneous phenotypes and conflicting impacts on survival outcomes in patients with colorectal cancer. Immunol Res. 2015;61(3):338-47. 
125. Badoual C, Hans S, Rodriguez J, Peyrard S, Klein C, Agueznay Nel H, Mosseri $\mathrm{V}$, Laccourreye $\mathrm{O}$, Bruneval P, Fridman WH, et al. Prognostic value of tumorinfiltrating CD4+ T-cell subpopulations in head and neck cancers. Clin Cancer Res. 2006;12(2):465-72.

126. Colotta F, Allavena P, Sica A, Garlanda C, Mantovani A. Cancer-related inflammation, the seventh hallmark of cancer: links to genetic instability. Carcinogenesis. 2009;30(7):1073-81.

127. Saito T, Nishikawa H, Wada H, Nagano Y, Sugiyama D, Atarashi K, Maeda Y, Hamaguchi M, Ohkura N, Sato E, et al. Two FOXP3(+)CD4(+) T cell subpopulations distinctly control the prognosis of colorectal cancers. Nat Med. 2016;22(6):679-84.

128. Barbi J, Pardoll D, Pan F. Metabolic control of the Treg/Th17 axis. Immunol Rev. 2013;252(1):52-77.

129. Sun L, Fu J, Zhou Y. Metabolism controls the balance of Th17/T-regulatory cells. Front Immunol. 2017;8:1632

130. Maj T, Wang W, Crespo J, Zhang H, Wang W, Wei S, Zhao L, Vatan L, Shao I, Szeliga $W$, et al. Oxidative stress controls regulatory $T$ cell apoptosis and suppressor activity and PD-L1-blockade resistance in tumor. Nat Immunol. 2017;18(12):1332-41.

131. shida T, Joh T, Uike N, Yamamoto K, Utsunomiya A, Yoshida S, Saburi Y, Miyamoto T, Takemoto S, Suzushima H, et al. Defucosylated anti-CCR4 monoclonal antibody (KW-0761) for relapsed adult T-cell leukemialymphoma: a multicenter phase II study. J Clin Oncol. 2012;30(8):837-42.

132. Arce Vargas F, Furness AJS, Solomon I, Joshi K, Mekkaoui L, Lesko MH, Miranda Rota E, Dahan R, Georgiou A, Sledzinska A, et al. Fc-optimized antiCD25 depletes tumor-infiltrating regulatory $T$ cells and synergizes with PD-1 blockade to eradicate established tumors. Immunity. 2017;46(4):577-86.

133. Dannull J, Su Z, Rizzieri D, Yang BK, Coleman D, Yancey D, Zhang A, Dahm P, Chao N, Gilboa E, et al. Enhancement of vaccine-mediated antitumor immunity in cancer patients after depletion of regulatory T cells. J Clin Invest. 2005;115(12):3623-33.

134. Nakagawa H, Sido JM, Reyes EE, Kiers V, Cantor H, Kim HJ. Instability of Helios-deficient Tregs is associated with conversion to a T-effector phenotype and enhanced antitumor immunity. Proc Natl Acad Sci USA. 2016;113(22):6248-53.

135. Li B, Saouaf SJ, Samanta A, Shen Y, Hancock WW, Greene MI. Biochemistry and therapeutic implications of mechanisms involved in FOXP3 activity in immune suppression. Curr Opin Immunol. 2007;19(5):583-8.

136. Park CS, Bang BR, Kwon HS, Moon KA, Kim TB, Lee KY, Moon HB, Cho YS Metformin reduces airway inflammation and remodeling via activation of AMP-activated protein kinase. Biochem Pharmacol. 2012;84(12):1660-70,

\section{Ready to submit your research? Choose BMC and benefit from:}

- fast, convenient online submission

- thorough peer review by experienced researchers in your field

- rapid publication on acceptance

- support for research data, including large and complex data types

- gold Open Access which fosters wider collaboration and increased citations

- maximum visibility for your research: over $100 \mathrm{M}$ website views per year

At BMC, research is always in progress.

Learn more biomedcentral.com/submissions 